\title{
The Contribution of Family Environment and Learning Motivation in Online Learning towards Learning Outcomes
}

\author{
Rahmadian \\ Vocational Technology and Education Department, Universitas Negeri Padang, Padang, Indonesia. \\ Email: rahmadianapril@gmail.com
}

Hasan Maksum

Vocational Technology and Education Department, Universitas Negeri Padang, Padang, Indonesia Email: makhasan@gmail.com

\section{A R T I C L E I N F O \\ Article history: \\ 1 Agustus 2020 Received in revised form \\ 20 September 2020 \\ Accepted 10 November 2020 \\ Available online 20 \\ November 2020

\begin{tabular}{l}
\hline Kata Kunci: \\
Lingkungan Keluarga, \\
Motivasi Belajar
\end{tabular} \\ Keywords: \\ Family Environment \\ Learning Motivation,}

\begin{abstract}
A B S T R A K
Penelitian ini bertujuan untuk mengukur kontribusi lingkungan keluarga dan motivasi belajar daring terhadap hasil belajar siswa pada mata pelajaran TIK kelas XI. Jenis penelitian adalah kuantitatif melalui dengan pendekatan korelasional. Populasi penelitian ini adalah seluruh siswa kelas XI yang terdiri dari 4 kelas dengan jumlah 101 orang siswa. Pengambilan sampel dalam penelitian ini dilakukan secara proportional random sampling dengan rumus slovin sebesar 81 responden. Instrumen pengumpulan data menggunakan kuesioner menggunakan Skala Likert, teknik analisis data diantaranya regresi sederhana dan regresi berganda. Hasil penelitian menunjukkan bahwa (1) Lingkungan keluarga berkontribusi terhadap hasil belajar sebesar 34,2\%; (2) Motivasi belajar berkontribusi terhadap hasil belajar sebesar 33,6\%d an (3) Lingkungan keluarga dan motivasi belajar berkontribusi bersama-sama terhadap hasil belajar sebesar 44,3\%. Jadi, lingkungan keluarga dan motivasi belajar berkontribusi bersama-sama terhadap hasil belajar siswa pada mata pelajaran layanan TIK.
\end{abstract}

\section{A B S T R A C T}

This study aims to measure the contribution of the family environment and online learning motivation to student learning outcomes in class XI ICT subject. This type of research is quantitative through a correlational approach. The population of this study was all students of class XI which consisted of 4 classes with a total of 101 students. Sampling in this study was carried out by proportional random sampling with the Slovin formula of 81 respondents. The data collection instrument used a questionnaire using a Likert scale, data analysis techniques including simple regression, and multiple regression. The results showed that (1) the family environment contributed to learning outcomes by $34.2 \%$; (2) Motivation to learn contributes to learning outcomes by $33.6 \%$ and (3) Family environment and learning motivation contribute together to learning outcomes by $44.3 \%$. Thus, the family environment and learning motivation contribute together to student learning outcomes in ICT service subjects

\section{Introduction}

Covid-19 is one of the biggest unsolved problems that exists. The existence of Covid-19 gives us more than one change in almost all fields (Chang et al., 2020; Fadlilah, 2020; Wong et al., 2020). One of the fields is education. There are so many policies and temporary solutions given by the government regarding the learning process, one of those is by learning at home. One of the approaches conducted by the teacher is online teaching and learning. Online learning is where the learning process is done online and has more flexibility than conservative learning (Anugrahana, 2020; Maulana \& Iswari, 2020). One of the subjects that are conducted online is ICT.

The ICT learning at school has a certain vision which is directing the students to use ICT tools optimally and based on target resulting in the correct information management to the learning process, working, and any other activities so that it makes the students are able to be creative, developing initiative, and developing both exploration and adaptation ability towards any changes. Based on the interview result with the ICT services teachers at SMAN 7 Solok Selatan, it can be concluded the passing grade (KKM in Indonesia) of the ICT subject is under the standard. These are the learning outcomes of the ICT services of the XI students shown in table 1. 
Table 1. The Average Mark of Semester 2 ICT Subject year 2019/2020

\begin{tabular}{ccccccc}
\hline \multirow{2}{*}{ Class } & Total Students & Mean & \multicolumn{2}{c}{$\begin{array}{c}\text { Students who passed } \\
\text { the grade }\end{array}$} & $\begin{array}{c}\text { Students who passed } \\
\text { the grade }\end{array}$ \\
\cline { 4 - 7 } & & & $\mathbf{F}$ & $\mathbf{\%}$ & $\mathbf{f}$ & $\mathbf{\%}$ \\
\hline XI.MIA & 24 & 68,19 & 11 & 45.8 & 13 & 54.2 \\
XI.IIS.1 & 26 & 67,18 & 10 & 38.5 & 16 & 61.5 \\
XI.IIS.2 & 26 & 67,87 & 10 & 38.5 & 16 & 61.5 \\
XI.IIS.3 & 25 & 66.81 & 8 & 32.0 & 17 & 68.0 \\
\hline Total & $\mathbf{1 0 1}$ & & $\mathbf{3 9}$ & $\mathbf{3 8 . 6}$ & $\mathbf{6 2}$ & $\mathbf{6 1 . 4}$ \\
\hline & & \multicolumn{2}{c}{ Source: ICT Teachers of SMAN 7 Solok Selatan }
\end{tabular}

Table 1 shows that the students of class XI ICT SMAN 7 Solok Selatan academic year 2019/2020 wh reached the passing grade standard (later will be mentioned by term "KKM") 78 amounted 38,6\% (39 students) meanwhile the students who did not amounted 61,4\% (62 students). This shows that there are some students of class XI SMAN 7 Solok Selatan who cannot fulfill the standard of the passing grade class. The learning outcome is defined as attitude, knowledge, and the changes in behavior that are acquired after conducting the learning process. The learning outcome is something that is achieved by the students after conducting the learning process, (Apriyanto et al., 2017; I. A. G \& Riastini, 2017). The learning result of the students is influenced by the internal and external factors of the students. One of the internal factors which influenced is learning motivation, meanwhile one of the external factors is the students' family (Kurniawan et al., 2018).

The family environment is one of the factors which influence the learning outcomes. The family environment is the first environment that becomes primary for someone in acquiring education (Nita \& Moeslihat, 2015; Shaleh, 2016). The family environment is the first environment that has a strong influence on someone compared to other types of environments. It is the tiniest group in the society which consists of the father, mother, children, and relatives (Murniati et al., 2019). The family environment, especially parents have specific roles in the growing up and the development of the children. Parents actively influence the characters shaping process of the children from the first time until they are ready to implement the characters in the real social environment (Subianto, 2013). Family factors that influence the achievement of the learning outcomes based on Slameto are parents' educational style, house atmosphere, the economic condition of the family, and the relation between family members (Shaleh, 2016). If the parents do not pay attention to educating their children, less optimum learning activities are achieved by the children. Thus, the family becomes the primary example for the students in building their characters in learning and the parents also have significant roles in providing the learning needs of their children as well as become good examples for them. Besides the external factors, the learning outcomes are also influenced by internal factors. Internal factors are factors that come from inside of the students, for example, learning motivation. Learning motivation is an energy change inside of someone which is marked by the development of curiosity and reaction to achieve some certain goals. Motivation also is defined by several efforts to provide certain conditions, thus someone wants and has desires to do something (Hasgimianti et al., 2018). Motivation is the willingness of the students to do learning activities to reach the goals and better learning outcomes.

Learning outcomes can be influenced by family environment and motivation. This statement can be proven by several previous research that has been conducted before. Rachmah et al., (2019) stated that there is a significant influence of family environment and family facilities towards the learning outcomes and learning motivation. Shaleh, (2016) showed that motivation, family factors, campus environment, and organization activities have positive impacts on the academic achievements. Ricardo \& Meilani, (2017) showed that there is a significant positive influence and interest towards the students' learning outcomes simultaneously and partially. The present research underlines both variables to improve the students' learning outcomes. Widiasih et al., (2018) showed variated media and students' learning motivation give a significant impact on economic learning outcomes. The use of variated media gives a positive influence on learning motivation and learning outcomes.

The aim of the research is to give a contribution to similar research which investigates similar topics. The significant difference between this research and the previous ones is the online learning process which is conducted today that demands the parents' roles in the activities since the learning process is fully done at home. Parents have a role to replace the roles of the teachers to accompany and supervise the students in learning. By carrying out this research, the expectation is put on giving a view on how motivation contributes toward the students' learning outcomes who participate in online learning. 


\section{Methodology}

The research was conducted using a quantitative method with a correlation approach. Arikunto (2010:313) stated that "correlational descriptive is a research which is created to determine the relationship of the different variables in a population. This research was conducted in Oktober 2020 at SMA Negeri 7 Solok Selatan academic year 2020/2021. The population of the research was all the students of grade XI in SMAN 7 Solok Selatan which consisted of 4 classes amounted to 101 students. The sample was chosen based on the proportional random sampling technique by using the solving formula. The researchers in this research determined a total of 81 students as samples. The source of data in this research was primary and secondary data. The primary data was gained directly as the questionnaire results of the respondents, which were the students of grade XI at SMAN 7 Solok Selatan. The secondary data was gained from the results of the mid-semester test of the ICT subject. The instrument used was a questionnaire using the Likert scale. The environment instrument was determined using several indicators based on the Slameto (2010) theory, such as parents' educational style, house atmosphere, the economic condition of the family and learning facilities, and the relation between family members. The learning motivation which was used in the present research was based on Sardiman's (2011) theory such as diligently making the task, facing difficulties well, showing interest in solving problems, independent in working, not easily bored, happy to find and solve problems. The analysis technique used were (1) data description which is the mean, median, modus, and standard deviation score. (2) normality test, homogeneity test, linearity test, and independent variable test. (3) Hypothesis using simple regression and double regression.

\section{Result and Discussion}

The hypothesis test in this research was carried out using simple regression analysis for the first and the second; meanwhile, the third hypothesis used double regression analysis. The explanation of hypothesis test in this research can be seen below. The first hypothesis which was tested in this research is contributed towards the learning outcomes of the students in the ICT subject at SMAN 7 Solok Selatan. To determine the contribution of the family environment to learning outcomes, simple regression was used. In accordance with the results of the calculation, the correlation coefficient between the family environment and learning outcomes was obtained 0,540 . He results showed that the coefficient relation $\left(\mathrm{ryx}_{1}\right)=0,585$ with $\rho=0,000<\alpha=0,05$. This means that there is a significant relationship between the family environment and learning outcomes. The coefficient of determination $\left(\mathrm{r}^{2}\right)$ is 0.342 . To determine whether or not the predictive relationship between the family environment and learning outcomes was formed, a simple regression analysis was performed. In accordance with the analysis, results obtained a regression equation $\hat{Y}=42,986+0,476 \mathrm{X}_{1}$. Furthermore, the regression coefficient significance test was carried out. The regression equation explains that $\hat{Y}=42,986+0,476 \mathrm{X}_{1}$ explained that each increase in the family environment by 1 scale would contribute to an increase in learning outcomes by 0,476 scales. While the value of learning outcomes already exists at 42,986 scales without the family environment. Furthermore, it can be interpreted that family environmental factors have a very significant predictive power in learning outcomes. The amount of the contribution of the family environment to student learning outcomes in the subject of ICT at SMAN 7 Solok Selatan is 34,2\%.

The second hypothesis tested in this study was learning motivation contributes to student learning outcomes in the subject of ICT at SMAN 7 Solok Selatan. To determine the contribution of learning motivation to learning outcomes, simple regression was used. Show that the correlation coefficient $\left(\mathrm{ryx}_{1}\right)=0,580$ with $\rho=$ $0,000<\alpha=0,05$. This means that there is a significant relationship between learning motivation and learning outcomes. The amount of the coefficient of determination $\left(\mathrm{r}^{2}\right)$ amounted to 0,336 . To determine the form of the predictive relationship between learning motivation and learning outcomes, a simple regression analysis was performed. In accordance with the analysis, results obtained a regression equation $\hat{Y}=36,374+0,312 \mathrm{X}_{2}$. The regression equation explains that $\hat{Y}=36,374+0,312 \mathrm{X}_{2}$ explained that each increase in learning motivation by 1 scale would contribute to an increase in learning outcomes by 0,312 scales. Meanwhile, the value of learning outcomes is 36,374 on the scale without learning motivation. Furthermore, it can be interpreted that the learning motivation factor has very significant predictive power on learning outcomes. The amount of contribution of learning motivation to student learning outcomes in the subject of ICT at SMAN 7 Solok Selatan is 33,6\%.

The third hypothesis tested in this study was the family environment and learning motivation together contribute to learning outcomes. To test this, a multiple correlation analysis was carried out. After analyzing, it was obtained the multiple correlation coefficients of family environment and learning motivation together with learning outcomes of 0,701 . The calculation results in Table 19 show that the correlation coefficient $\left(\operatorname{ryx}_{1} \mathrm{x}_{2}\right)=$ 
0,666 with $\rho=0,000<\alpha=0,05$. Thus, it can be stated that there is a very significant relationship between the family environment and learning motivation together with student learning outcomes in service subject of ICT at SMAN 7 Solok Selatan is 44,3\%. To determine whether or not the predictive relationship between the family environment and learning motivation on learning outcomes was carried out, multiple regression analysis was performed and regression equations are obtained $\hat{Y}=29,343+0,314 \mathrm{X}_{1}+0,202 \mathrm{X}_{2}$. Furthermore, the regression coefficient significance test was carried out. It can be seen that the $t$ value of the family environment regression coefficient is 3,870 and the significance level is 0,000 , while the $t$ regression coefficient of learning motivation is 3,761 with a significance level of 0,000 . This means that the regression coefficients of 0.314 and 0.202 are significant and can be used to predict learning outcomes.

The regression model is $\hat{Y}=29,343+0,314 \mathrm{X}_{1}+0,202 \mathrm{X}_{2}$ which explains that direction coefficient $\mathrm{X}_{1}$ is 0,314 and coefficient $X_{2}$ is 0,202 . This means that every increase in the family environment by 1 scale will contribute to an increase in learning outcomes by 0.314 scales and an increase in learning motivation by 1 scale will contribute to the addition of learning outcomes value of 0.202 . Before the value of learning outcomes is a constant, namely 29.343 scales without any influence from the two predictors. On the basis of the above calculations, the three hypotheses tested in this study can be accepted in confidence $95 \%$. The magnitude of the contribution of the family environment and learning motivation to student learning outcomes in service subject of ICT at SMAN 7 Solok Selatan is $44,3 \%$.

The results of data analysis and hypothesis testing indicate that the three hypotheses tested in this study can be accepted. The results of the data analysis show that the family environment and learning motivation either individually or collectively have a meaningful contribution or role to play in improving student learning outcomes in service subject of ICT at di SMAN 7 Solok Selatan. The first finding, the results of this study indicate that the family environment provides a significant contribution to student learning outcomes in service subjects ICT at SMAN 7 Solok Selatan by 32.2\%. Furthermore, the regression equation obtained by the family environment variable with learning outcomes, namely $\hat{Y}=42,986+0,476 \mathrm{X}_{1}$. The regression equation illustrates that the better the family environment, the higher the contribution to student learning outcomes.

The family environment is one of the factors that influence learning outcomes. The family environment is the first and foremost environment for someone to get an education (Nita \& Moeslihat, 2015; Shaleh, 2016). The family environment is the first environment that has a strong influence on the individual compared to other environments. The family environment is the smallest group in a society consisting of the father, mother, children, and relatives (Murniati et al., 2019). The family environment, especially parents, plays a role in the development and growth of children. Family factors that affect learning achievement, namely, how parents educate, home atmosphere, family economic conditions, parents' attention, and relationships between family members (Shaleh, 2016). In addition to these factors, the high and low education of parents, the parents' income, the close relationship between parents and children, all of which affect the success of children's learning, so that parents can be defined as matters, the child's success in learning depends on how people learn parents pay attention to their children in learning to achieve achievement. If the parents do not pay attention to educating their children, this will certainly result in less optimal learning activities for children.

To increase the ICT learning outcomes, children also need the support of the family, the family environment that is comfortable can support them to concentrate on learning ICT subject at home. In addition, the condition of the house also needs to be arranged neatly and cleanly so that it can create a sense of comfort and coolness which allows children to prefer to stay at home to study. The availability of study equipment of ICT adequate will also support the learning process at home. The economic condition of parents is good, it is very supportive for students to provide the facilities and infrastructure needed by students to learn ICT well, such as students who can buy textbooks of ICT and buy a computer to learn ICT learning computer at home. With the computer, students can repeat the material given by the teacher at home. The results of this study are supported by Slameto, (2010) that a child who is learning needs learning facilities like, study rooms, tables, chairs, lighting, writing instruments, books, and so on. Therefore, it is hoped that the role of the family is to provide adequate facilities and infrastructure for student learning activities at home, especially for the availability of a comfortable and quiet study room, so that later students can comfortably study at home so that their learning achievement can increase in the future. So, the findings of this study are in accordance with the mindset put forward in the conceptual framework in which good family environmental conditions tend to contribute so that children's learning outcomes are good. Conversely, if the family environment is not good, a large trend will have a negative impact on student development.

This finding is supported by Daud et al., (1994) shows that there are eight sub-variables of the family environment that have a real influence on children's learning achievement and may be applied or manipulated to improve children's learning achievement, namely the habits of children getting up early, learning facilities at 
home, the amount of independent study time, the learning situation at home, the frequency of school absences, group study, being late for class, and additional education. The research result of Murti \& Heryanto, (2016) states that the quality of social interaction in the family environment has a significant effect on student achievement. Then the research conducted by (Sutardi, 2016) states that the family environment is the first and foremost environment that affects children's development and behavior as well as children's learning achievement.

The second finding, the results of this study indicate that learning motivation makes a significant contribution to student learning outcomes in the subject of ICT at SMAN 7 Solok Selatan is 33,6\%. Furthermore, the regression equation obtained by the learning motivation variable with learning outcomes, namely $\hat{Y}=36,374+0,312 \mathrm{X}_{2}$. The regression equation illustrates that the better the learning motivation, the higher the contribution to student learning outcomes.

Motivation to learn is a change in energy in a person which is marked by the emergence of feelings and reactions to achieve goals. Motivation is also interpreted as a series of efforts to provide certain conditions so that someone wants and wants to do something (Hasgimianti et al., 2018). Motivation is the desire of students to carry out learning activities to achieve better learning outcomes or outcomes. Motivation is one of the factors that can encourage students to learn so that the learning process becomes higher quality (Emda, 2018; Oktiani, 2017). With motivation will grow the urge to do something in relation to the achievement of learning objectives. Increasing student learning motivation is important for the learning process because motivation will affect how teachers and students interact with learning material. Therefore, to improve the quality of learning, teachers must be able to motivate students to study harder. The ICT subject is is a fairly difficult subject because it requires reasoning, understanding, analysis, accuracy, and thoroughness. Therefore, we need high motivation to learn ICT so that the learning outcomes of ICT learning. Motivation is an inner factor (inner) functions to activate, guide, and maintain one's behavior continuously. With motivation, there will be a desire to learn ICT from within students and guide students to learn more efficiently to achieve optimal learning outcomes.

The result of the present research is in line with Lestari (2017) who states that There is an effect of learning motivation on students' mathematics learning outcomes. Then the research conducted by (Chulsum, 2017) There is a significant and positive influence between learning motivation on learning outcomes of high school students economics. Then the research conducted by (Utari, 2016) stated that learning motivation that contributed positively was $38.30 \%$ and linear with a confidence level of $95 \%$, which means that if student learning motivation increases, the contribution to learning outcomes will also be even greater. Ricardo \& Meilani, (2017) shows a positive and significant influence of interest in learning and motivation to learn on student learning outcomes either simultaneously or partially. This article emphasizes the importance of these two variables in an effort to improve student learning outcomes. The research of Widiasih et al., (2018) shows that varied media and student motivation have an impact on learning outcomes in economic subjects. The use of various media has a positive and significant effect on learning motivation. The use of varied media has a positive and significant effect on learning outcomes, and learning motivation has a positive and significant effect on learning outcomes.

So, motivation has a positive effect on ICT learning outcomes. If the students' motivation is high, they will focus more on learning ICT, be enthusiastic, and not easily give up on learning in order to achieve optimal learning outcomes. Meanwhile, students, whose motivation is low will not focus on learning, tend to be lazy to learn, and easily give up which results in low ICT learning outcomes.

The third finding, the results of this study indicate that the family environment and learning motivation together contribute to improving student learning outcomes. The contribution of the family environment and learning motivation to student learning outcomes is $44,3 \%$. The third finding, the results of this study indicate that the family environment and learning motivation together contribute to improving student learning outcomes. The contribution of the family environment and learning motivation to student learning outcomes is $\hat{Y}$ $=29,343+0,314 X_{1}+0,202 X_{2}$. This shows that the family environment and learning motivation together contribute to student learning outcomes.

Data analysis shows that student learning outcomes are significantly influenced by the family environment and learning motivation, both individually and collectively. The family environment and learning motivation are two very important factors to be considered by all parties in SMAN 7 Solok Selatan. If the family environment is well developed and learning motivation is high, then student learning outcomes will increase. The family environment and learning motivation have a positive influence on student learning outcomes. If the family environment is harmonious and fun, it will make children have good motivation in learning (Setyawati \& Subowo, 2018).

Susanto (2013:12) states that the learning outcomes achieved by students are the result of the interaction between various factors that influence both internal and external factors. Internal factors are factors that come 
from within students that affect their learning ability. These internal factors are intelligence, interest, and attention, learning motivation, persistence, attitudes, study habits, and physical and health conditions. While external factors come from outside the students that affect learning outcomes, namely family, school (the learning model used by teachers), and society.

The results of this study are in line with research conducted by (Setyawati \& Subowo, 2018) learning motivation, family environment, and the role of teachers simultaneously have a positive and significant effect on student learning discipline. Rachmah et al., (2019) suggest that there is a significant influence on the family environment, family facilities on learning outcomes, and learning motivation. Research by Shaleh, (2016) shows that motivation, family factors, campus environment, and organizational activity have a positive and significant effect on academic achievement.

\section{Conclusion}

Based on the research that was carried out, it can be concluded that: family environment contributes to the students' learning outcomes on the ICT subject at SMAN 7 Solok Selatan amounted 34,2\%. This means that a good family environment will increase the students' learning outcomes. Learning motivation contributes to the learning outcomes on the ICT subject at SMAN 7 Solok Selatan amounted 33,6\%. This means that with the existence of high learning motivation, the learning outcomes will increase as well. The family environment and motivation contribute together toward the students' learning outcomes on the ICT subject at SMAN 7 Solok Selatan amounted $44,3 \%$. This means that both variables are hand in hand in influencing the learning outcomes of the students.

\section{Acknowledgment}

Firstly, a bunch of thanks is presented to Dr. Hasan Maksum, M.T. Secondly, to the contributor lecturer, Wawan Purwanto, S.Pd, M.T, Ph.D. and thirdly to Dr. Eko Indrawan, S.T, M.Pd.

\section{References}

Anugrahana, A. (2020). Hambatan, Solusi dan Harapan : Pembelajaran Daring Selama Masa Pandemi Covid-19 Oleh Guru Sekolah Dasar. Scholaria: Jurnal Pendidikan Dan Kebudayaan, 10(3), 282-289. https://ejournal.uksw.edu/scholaria/article/view/4033

Apriyanto, B., Nurdin, E. A., Ikhsan, F. A., \& Kurniawan, F. A. (2017). Penerapan Pembelajaran Berbasis Masalah Untuk Meningkatkan Aktivitas Dan Hasil Belajar Siswa Dalam Memahami Lingkungan Hidup Pada Mata Pelajaran Ips Di Smp Negeri 2 Sukodono. Jurnal Pendidikan Ekonomi: Jurnal Ilmiah Ilmu Pendidikan, Ilmu Ekonomi Dan Ilmu Sosial, 11(2), 7. https://doi.org/10.19184/jpe.v11i2.5727

Chang, T. Y., Hong, G., Paganelli, C., Phantumvanit, P., Chang, W. J., Shieh, Y. S., \& Hsu, M. L. (2020). Innovation of dental education during COVID-19 pandemic. Journal of Dental Sciences, 155. https://doi.org/10.1016/j.jds.2020.07.011

Chulsum, U. (2017). Pengaruh Lingkungan Keluarga, Kedisiplinan Siswa, Dan Motivasi Belajar Terhadap Hasil Belajar Ekonomi Siswa Di Sma Negeri 7 Surabaya. Jurnal Ekonomi Pendidikan Dan Kewirausahaan, 5(1), 5-20. https://doi.org/http://dx.doi.org/10.26740/jepk.v5n1.p5-20

Daud, H., Sufiati, C., Abdullah, Z., \& Amrusi, A. (1994). Lingkungan Keluarga Anak-Anak Berprestasi Tinggi dan Anak-ANak Berprestasi Rendah di SMA Negeri Kabupaten Pidie Sigli. Jurnal Ilmu Pendidikan, I(2), 108-116. https://doi.org/http://dx.doi.org/10.17977/jip.v1i2.2263

Emda, A. (2018). Kedudukan Motivasi Belajar Siswa Dalam Pembelajaran. Lantanida Journal, $5(2), 172$. https://doi.org/10.22373/lj.v5i2.2838

Fadlilah, A. N. (2020). Strategi Menghidupkan Motivasi Belajar Anak Usia Dini Selama Pandemi COVID-19 melalui Publikasi. Jurnal Obsesi: Jurnal Pendidikan Anak Usia Dini, 5(1), 373. https://doi.org/10.31004/obsesi.v5i1.548

Hasgimianti, Putri, R. D., \& MRA, R. R. (2018). Motivasi Belajar Siswa yang Berlatar Belakang Budaya Melayu dan Jawa. Educational Guidance and Counseling Development Journal, 1(1), 52. https://doi.org/10.24014/egcdj.v1i1.4948

I. A. G, S. U., \& Riastini, P. N. (2017). Penerapan Metode Take and Give Untuk Meningkatkan Hasil Belajar Ipa Siswa Kelas Iv. Jurnal Ilmiah Sekolah Dasar, 1(1), 51-58. https://doi.org/http://dx.doi.org/10.23887/jisd.v1i1.10118 
Kurniawan, B., Wiharna, O., \& Permana, T. (2018). Studi Analisis Faktor-Faktor yang Mempengaruhi Hasil Belajar pada Mata Pelajaran Teknik Listrik Dasar Otomotif. Journal of Mechanical Engineering Education, 4(2), 156. https://doi.org/10.17509/jmee.v4i2.9627

Lestari, W. (2017). Pengaruh Kemampuan Awal Matematika dan Motivasi Belajar terhadap Hasil Belajar Matematika. Jurnal Analisa, 3(1), 76. https://doi.org/10.15575/ja.v3i1.1499

Maulana, H. A. \&, \& Iswari, R. D. (2020). Analisis Tingkat Stres Mahasiswa Terhadap Pembelajaran Daring Pada Mata Kuliah Statistik Bisnis di Pendidikan Vokasi. Jurnal Ilmiah Kependidikan, 14(1), 17-30. https://doi.org/10.30595/jkp.v14i1.8479

Murniati, M., Sulistyo, S., \& Yudiono, U. (2019). Pengaruh Kepribadian, Pengetahuan Kewirausahaan, Kreativitas Dan Lingkungan Keluarga Terhadap Minat Berwirausaha. Jurnal Riset Pendidikan Ekonomi, 4(2), 1-6. https://doi.org/10.21067/jrpe.v4i2.3908

Murti, S., \& Heryanto, H. (2016). Pengaruh Kualitas Interaksi Sosial Di Lingkungan Keluarga Terhadap Prestasi Belajar Siswa (Studi Kasus Di Sma Negeri 5 Samarinda). Al Ibtida: Jurnal Pendidikan Guru MI, 3(2), 253-268. https://doi.org/10.24235/al.ibtida.snj.v3i2.898

Nita, P., \& Moeslihat, R. (2015). Pengaruh Lingkungan Keluarga Dan Lingkungan Sekolah Terhadap Prestasi Belajar Siswa Pada Mata Pelajaran Akuntansi Di Kelas Xi Ips Sma Pasundan 8 Bandung. Jurnal Pendidikan Akuntansi \& Keuangan, 3(1), 13. https://doi.org/10.17509/jpak.v3i1.15383

Oktiani, I. (2017). Kreativitas Guru dalam Meningkatkan Motivasi Belajar Peserta Didik. Jurnal Kependidikan, 5(2), 216-232. https://doi.org/10.24090/jk.v5i2.1939

Rachmah, L. L., Sunaryanto, \& Yuniastuti. (2019). Pengaruh Lingkungan Keluarga dan Fasilitas Keluarga terhadap Motivasi Belajar dan Hasil Belajar. Journal of Chemical Information and Modeling, 53(9), 1689-1699. https://doi.org/http://dx.doi.org/10.17977/jptpp.v4i9.12701

Ricardo, R., \& Meilani, R. I. (2017). Impak Minat dan Motivasi Belajar Terhadap Hasil Belajar Siswa. Jurnal Pendidikan Manajemen Perkantoran, 2(2), 79. https://doi.org/10.17509/jpm.v2i2.8108

Setyawati, V., \& Subowo, S. (2018). Pengaruh Motivasi Belajar, Lingkungan Keluarga Dan Peran Guru Terhadap Disiplin Belajar Siswa. Economic Education Analysis Journal, 7(1), 29-44.

Shaleh, M. (2016). Pengaruh Motivasi, Faktor Keluarga, Lingkungan Kampus Dan Aktif Berorganisasi Terhadap Prestasi Akademik. Phenomenon: Jurnal Pendidikan MIPA, 4(2), 109. https://doi.org/10.21580/phen.2014.4.2.122

Slameto. (2010). Belajar dan Faktor-Faktor yang Mempengaruhinya. Rineka Cipta.

Subianto, J. (2013). Peran Keluarga, Sekolah, Dan Masyarakat Dalam Pembentukan Karakter Berkualitas. Edukasia: Jurnal Penelitian Pendidikan Islam, 8(2), 331-354. https://doi.org/10.21043/edukasia.v8i2.757

Sutardi, S. (2016). Harmoni Sosial : Jurnal Pendidikan IPS Volume 3 , No 2 , September 2016 ( 188-198 ) Online: http://journal.uny.ac.id/index.php/hsjpi Harmoni Sosial: Jurnal Pendidikan IPS. Harmoni Sosial: Jurnal Pendidikan IPSJurnal Pendidikan IPS, 3(2), 188-198. https://doi.org/https://doi.org/10.21831/hsjpi.v3i2.8400

Utari, R. (2016). Kontribusi motivasi belajar dan kebiasaan belajar siswa kelas 1 teknik audio video terhadap hasil belajar pada mata diklat pkdle di smk n 1 padang. Jurnal Ilmiah Pendidikan Teknik Elektro, 1(2), 108-114. https://doi.org/http://dx.doi.org/10.30870/volt.v1i2.2877

Widiasih, R., Widodo, J., \& Kartini, T. (2018). Pengaruh Penggunaan Media Bervariasi Dan Motivasi Belajar Terhadap Hasil Belajar Mata Pelajaran Ekonomi Siswa Kelas Xi Ips Sma Negeri 2 Jember Tahun Pelajaran 2016/2017. JURNAL PENDIDIKAN EKONOMI: Jurnal Ilmiah Ilmu Pendidikan, Ilmu Ekonomi Dan Ilmu Sosial, 11(2), 103. https://doi.org/10.19184/jpe.v11i2.6454

Wong, G. L. H., Wong, V. W. S., Thompson, A., Jia, J., Hou, J., Lesmana, C. R. A., Susilo, A., Tanaka, Y., Chan, W. K., Gane, E., Ong-Go, A. K., Lim, S. G., Ahn, S. H., Yu, M. L., Piratvisuth, T., \& Chan, H. L. Y. (2020). Management of patients with liver derangement during the COVID-19 pandemic: an AsiaPacific position statement. The Lancet Gastroenterology and Hepatology, 5(8), 776-787. https://doi.org/10.1016/S2468-1253(20)30190-4 